\title{
Impacts of Land Cover Change on Conservation, a Linkage of Spatial Analysis and Anthropogenic Activities in Tanzania
}

\author{
Herman N. Nyanda ${ }^{*}$, Juma J. Kegamba ${ }^{2}$, Kamaljit K. Sangha ${ }^{3}$ \\ ${ }^{1}$ Tanzania Wildlife Authority (TAWA), Morogoro, Tanzania \\ ${ }^{2}$ College of African Wildlife Management, Mweka, Moshi, Kilimanjaro, Tanzania \\ ${ }^{3}$ Research Institute for the Environment and Livelihoods, Charles Darwin University, Darwin, NT, Australia \\ Email: `hermanic2010@gmail.com, ^herman.nyanda@tawa.go.tz,jkegamba@mwekawildlife.ac.tz, jkegamba@yahoo.com, \\ Kamaljit.Sangha@cdu.edu.au
}

How to cite this paper: Nyanda, H. N., Kegamba, J. J., \& Sangha, K. K. (2018). Impacts of Land Cover Change on Conservation, a Linkage of Spatial Analysis and Anthropogenic Activities in Tanzania. Open Journal of Forestry, 8, 344-361. https://doi.org/10.4236/ojf.2018.83022

Received: June 11, 2018

Accepted: July 17, 2018

Published: July 20, 2018

Copyright ( $) 2018$ by authors and Scientific Research Publishing Inc. This work is licensed under the Creative Commons Attribution International License (CC BY 4.0).

http://creativecommons.org/licenses/by/4.0/

\section{cc) (i) Open Access}

\begin{abstract}
We used spatial analysis to assess the Land Use Land Cover (LULC) changes, and studied the impacts of LC changes on conservation of buffer zone of the Selous Game Reserve (SGR) and their implication on community's livelihood in Vikumbulu Ward of Kisarawe District, Tanzania. Socio-economic data from Kisarawe District and TNBS were linked to spatial data to offer an integrated perspetive of LULC change in the Ward. Three cloud free image dates of 1998, 2011 and 2015 were analysed using System for Automated Geoscientific Analyses (SAGA) GIS for three categories of land cover, i.e. forest, wooded grassland and bare land/settlements/cultivation. Vikumbulu demographic and socio-economic data were linked to spatial data applying distance as a function of LULC change. Spatial analysis has shown a decreasing trend of forest and woodland cover in Vikumbulu Ward between 1998 and 2015. The sharp decline indicates increasing social economic activities such as shifting agriculture and charcoal burning as an outcome of population growth and poverty. Rapid conversion of forest cover to wooded grassland occurred between 1998 and 2015 in Vikumbulu Ward. However, loss of forest cover was associated with a decreasing trend in wooded land in the ward between 2011 and 2015. As there was only $0.15 \%$ area under crop cultivation in Vikumbulu until 2015, it is highly likely that LC change is caused by charcoal burning and shifting cultivation. This study suggests developing integrated strategies that target LULC change, conservation and people's livelihoods to effectively improve the current situation in rural areas of Tanzania.
\end{abstract}




\section{Keywords}

Land Use and Land Cover Changes, Poverty, Charcoal, Vikumbulu Wards, SGR Buffer Zones

\section{Introduction}

Impact of Land Use and Land Cover (LULC) changes is of great concern for community livelihood and conservation globally. About $40 \%$ of a global land once covered by natural vegetation has been transformed into agricultural cropland (Meiyappan \& Jain, 2012). The rising demand for materials to support human living has facilitated competing land use and land cover changes (Hartemink et al. 2008; Meiyappan, 2017).

The drivers of land cover change vary across the local, regional and global scales (Lambin et al., 2001; Long et al., 2007), but they ultimately impact across all the three scales (Foley et al., 2005; Cotillon, 2013). The LULC changes cause loss of 13 million ha of world's tropical forest each year including 14,000 and 40,000 species (Kremen et al., 2000; Millennium Ecosystem Assessment, 2005). Unfortunately, most forest loss occurs in the developing world (Sunderlin et al., 2005) where expansion and development of urban and peri-urban areas and associated socio-economic activities have resulted in significant vegetation changes (Asselen \& Verburg, 2013). Population growth coupled with high demand for food, charcoal, timber and poles in urban areas are the key drivers contributing to natural resources degradation in rural areas (Kangalawe \& Lyimo, 2010; MacKenzie \& Hartter, 2013).

In Tanzania, forest and woodland areas cover over 48 million hectares of land (Tremblay \& Lowry, 2016). Apart from being a source of income and employment for many residents, forests provide a wide range of environmental services such as bush food, clean air, and ecotourism and water regulation in the catchment areas. Despite their benefits, Tanzanian forests are under great pressure. A forest inventory by the Tanzania Forest Services Agency (TFS) in 2015 revealed that more than $90 \%$ of mainland is dependent on energy derived from wood/charcoal, causing fast depletion of forest resources (The National Forest Resources Monitoring and Assessment (NAFORMA, 2015). Similar findings by Global Forest Resources Assessment (GFRA, 2015) revealed that more than 5.86 million hectares $(\sim 10 \%)$ of Tanzania's forest cover was lost between 2000 to 2015 due to deforestation and degradation. The rate of forest cover loss in Tanzania is approximately 373,000 hectares per year, the highest in East Africa, which is estimated to cost $\$ 3.5$ billion by 2033 (Tremblay \& Lowry, 2016).

It should be noted that more than $57 \%$ of forest cover in Tanzania is under village management or general land management with limited protection (Luoga et al. 2005; Bongers \& Tennigkeit, 2010). And, the rates of forest cover loss are approximately eight times higher in these unprotected areas than protected areas 
such as forest reserves and national parks (Tabor et al., 2010). Lack of effective and sustainable measures on how to utilize forest resources in villages has resulted in deforestation and degradation (Bongers \& Tennigkeit, 2010). Several forest products such as timber, poles and charcoal, harvested from these unprotected areas, are sold in the urban centres. For example, the source of charcoal for Tanzania's main commercial centre-Dar es Salaam was the villages in proximity of 60 kilometres radius in 1990s, which increased to 300 kilometers in 2000s (Tremblay \& Lowry, 2016).

The key factors for land cover changes include wood extraction and expansion of agriculture and settlement coupled with poverty, population growth, lack of employment and corruption (Makunga \& Misana, 2017). LC change is a major challenge in Tanzania despite the great efforts for establishing Community Based Conservation areas and Participatory Forest Management (PFM) (Sunseri, 2005; Treue et al., 2014).

Therefore, assessment of LC changes over time is crucial for monitoring conservation management, land use and LC changes including the drivers that cause those changes (Turner et al. 1994; Fisher, 2011). Many studies have provided descriptive statistics on LC changes on a global scale (Goldewijk \& Ramankutty, 2004; Ramankutty et al., 2008; Hansen et al., 2013) but few try to understand these changes at local level (Lambin et al., 2003; Hartemink et al., 2008), especially in Tanzania.

This study presents a spatial analysis of land cover change over time (1998 to 2015) of a rural area in Tanzania, abutting an internationally famous Selous Game Reserve (SGR). The main goal was to find out why and how land cover is changing. For this, the study included a focus on socio-economic activities that occur in the neighbouring urban centre of Dar es Salaam, and posits an integrated analysis to inform conservation and local land management as well as future policy of land use for regional and rural areas of Tanzania.

\section{Study area description}

This study was conducted at Vikumbulu Ward in Kisarawe District, Pwani Region of Tanzania. Kisarawe districts lies between 38.26E and 39.13E to 6.78S and $7.58 \mathrm{~S}$ while Vikumbulu Ward is located between $38.30 \mathrm{E}$ and $38.67 \mathrm{E}$ to $7.31 \mathrm{~S}$ and 7.56S. The ward occupies an area of $1003 \mathrm{~km}^{2}$ with a population density of 3.2 inhabitants per $\mathrm{km}^{2}$ (Tanzania National Bureau of Standards-TNBS, 2012). This particular ward was selected because it abuts world famous, Selous Game Reserve (50,000 $\mathrm{km}^{2}$ area), which is located in southeast Tanzania, representing $5 \%$ of Tanzania's total land mass (Caro et al., 2009). Additionally, this ward is close $(98 \mathrm{~km})$ to the main business centre, Dar-es-Salaam (Figure 1). The ward consists of very few ridges and hills in the northeastern corner with elevation ranging between $285 \mathrm{~m}$ to $436 \mathrm{~m}$ above the sea level (Figure 1(d)).

Vikumbulu Ward have bimodal rainfall pattern with the annual mean of 1236 mm (Mdemu et al., 2010; Lupala et al., 2014). The long rainy season spans from March to June, short rainy season from November to January, and the dry season from June to October. Temperature ranges from $24^{\circ} \mathrm{C}-31^{\circ} \mathrm{C}$ with low 


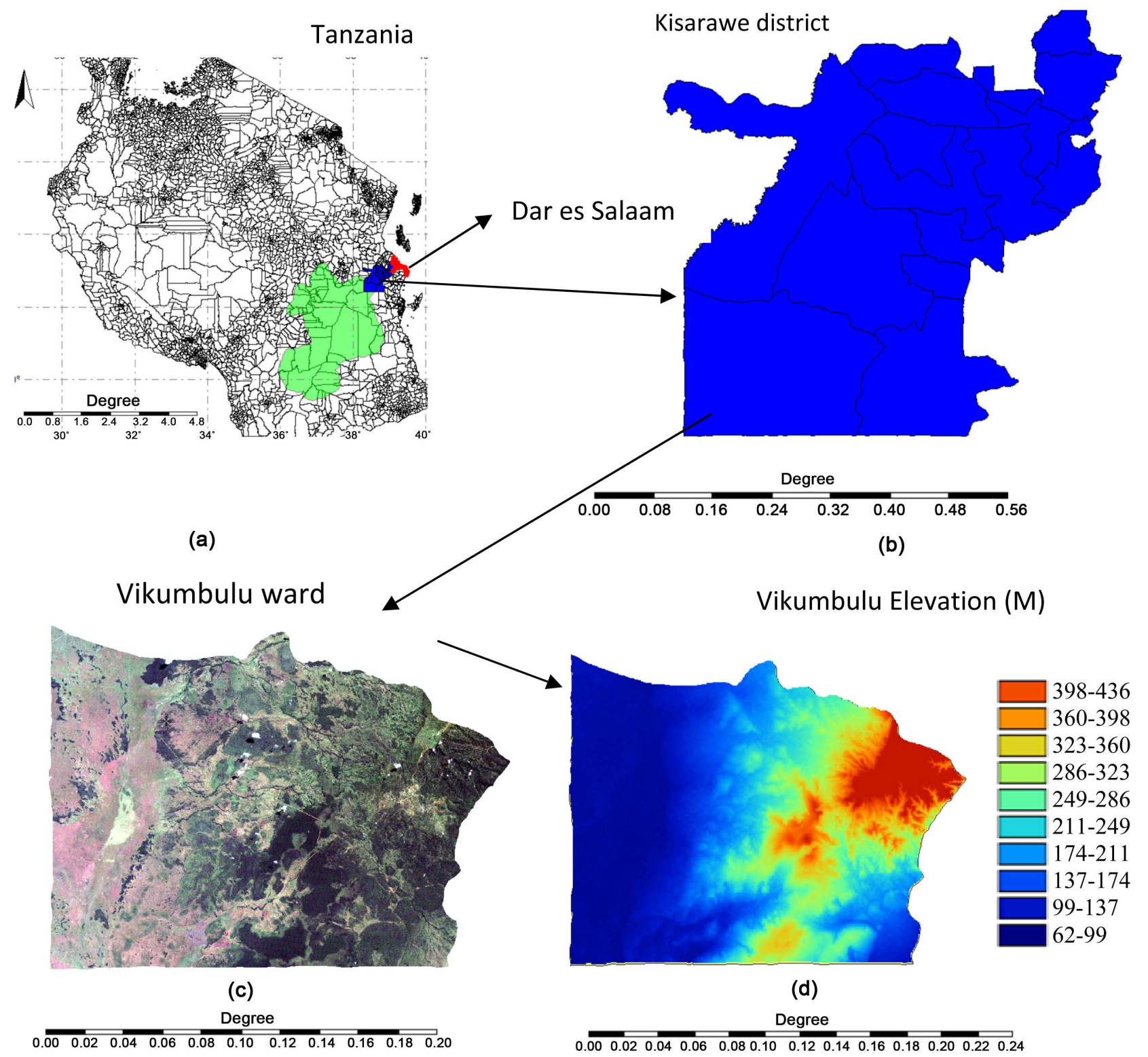

Figure 1. Study location (a) Map of Tanzania showing location of Selous Game Reserve (in green), Dar es Salaam city (red) and Kisarawe district (blue) (b) Kisarawe District and Vikumbulu Ward (c) Vikumbulu Ward topography (d) Vikumbulu Ward elevation.

temperatures from June to November and high from December to April (Mdemu et al., 2010; Lupala et al., 2014). However, the rainfall has shown a general trend of decline since 1981 (Kashaigili et al., 2014).

The natural vegetation at Vikumbulu Ward constitutes an extension of protected areas buffer zones surrounding SGR predominated by wet miombo woodlands that extend from the sea level to a height of $1600 \mathrm{~m}$ above the sea level (Bongers \& Tennigkeit, 2010). It also contains some of the valuable timber wood species such as Afzelia quanzensis (Pod mahogany), Pterocarpus angolensis and Dalbergia melanoxylon (African Blackwood) (Bongers \& Tennigkeit, 2010). 
The main economic activities in Vikumbulu Ward include subsistence small-scale agriculture, fishing and charcoal production (TNBS, 2012). The ward's cropland area varies from 0.5 - 1 ha per household (Mandari, 2010), supporting an average family of 4.6 members (Habib-Mintz, 2010). Both forestry and agriculture products are used for domestic consumption and income (TNBS, 2012).

\section{Materials and Methods}

Spatial data for 1998, 2011 and 2015 images were obtained from landsat satellite in glovis (http://glovis.usgs.gov/), earth explorer website (http://earthexplorer.usgs.gov/) and libra (https://libra.developmentseed.org/) from path 166 and row 65. Landsat satellite has a multispectral sensor acquiring images in several spectral bands at spatial resolution of 28 metres and temporal resolution of 16 days (Khorram et al., 2016). The image offers details vegetation cover, extent of the cover and changes over time for mapping and classifying large habitats (Ned, 2010). Three image sets of 1998, 2011 and 2015 (Table 1) from May to December, were chosen to distinguish different land use patterns and vegetation types such as forests, wooded grasslands, cultivated land or riparian area. The study was therefore undertaken during dry season which is mostly characterised low humid, temperature wind and drought.

Similarly, Shuttle Radar Topographic Mission (SRTM) Tile Grabber (http://dwtkns.com/srtm/) was used for Digital Elevation Modal (DEM) of the study region. DEM data was used to characterise the terrain, describing how it may have influenced LC changes. The study also analysed demographic data such as population growth, agriculture yields and area under cultivation in Vikumbulu over 20 years, from 1995 to 2015. These data were obtained from Kisarawe District Council. The percentage land cover changes of the spatial data were then compared to assess changes overtime, and then linked to demographic, socio-economic data of the study area for analysis

Classification and images analysis was conducted using System for Automated Geoscientific Analyses (SAGA) GIS version 2.1.4 and projected to UTM zones 37S. Visible, NIR and thermal bands were used in the analysis, detection and mapping of land cover types as shown in Table 2 based on Koharram et al. (2016). Object Based Image Analysis (OBIA) classification was performed to obtain land cover maps of the study area for each image date.

Table 1. Landsat satellite image selection criteria of Kisarawe district for land cover classification and analysis

\begin{tabular}{ccc}
\hline Image & Acquisition date & Cloud cover \\
\hline Landsat8 & 3-Aug-15 & $9 \%$ \\
Landsat5 & 7-Jul-11 & $4 \%$ \\
Landsat5 & 16-May-98 & $<10 \%$ \\
\hline
\end{tabular}


Table 2. Land cover classes in Vikumbulu Ward.

\begin{tabular}{cl}
\hline Class name & \multicolumn{1}{c}{ Description } \\
\hline Forest cover (FC) & $\begin{array}{l}\text { A landscape characterised by high tree density. The forest } \\
\text { cover in current study refers to both closed and open forest. } \\
\text { The open forest is distinguished from wooded grassland } \\
\text { by lack of grasses and proximity of trees. }\end{array}$ \\
A landscape with sparsely distributed trees dominated by \\
grasses or thickets of shrubs together with landscape \\
characterised by vegetation growing along the river or \\
valley were treated as one class. Because the images were \\
taken in the dry season there were no clear water bodies, \\
but swampy vegetation such as marshes and other \\
swampy thickets were identified \\
Hooded grassland (WG) \\
Human settlements, cultivation and bare land were treated as \\
one class due to their similar spectral properties, because of \\
difficulties in distinguishing them. Grassland in this \\
category includes cropped, cleared or harvested land and \\
cannot always be distinguished from bare land.
\end{tabular}

The accuracy assessment was conducted using an error matrix method to determine the correlation between classified images of 2015 and the ground truth, as described by Khorram et al. (2016). An overall accuracy of $74 \%$ was obtained (Table 3), satisfactory to proceed with analyses. SAGA was used for all the spatial and statistical analyses of all images date were calculated in and then exported to Microsoft Excel 2010 for calculations and results.

\section{Limitations of the spatial analysis}

Images with higher percentage of cloud cover might obscure land cover. Spectral mixing between bare land, grassland, settlements and cultivation for the study areas made it difficult to distinguish different features or LULC cover underneath so these are categorised as bare land. Quantifying charcoal and timber as the drivers of LC change was difficult due to lack of charcoal harvest data for the ward despite the fact that charcoal business is prevalent there.

\section{Results}

\subsection{Land Cover Changes in Vikumbulu Ward from 1998 to 2015}

The total ward area of 99,660 ha underwent significant LULC changes in the recent past 17 years. In 1998, 54\% of the land was dominated by forest cover whereas only $14 \%$ that cover remained by 2015 (Figure 2(a)). A rapid increase in wooded grassland and thicket corresponded directly with a decrease in forest cover between 1998 and 2011. However, a decrease in wooded grassland and thicket from 2011 to 2015 was linked with a sharp increase in bare land, settlements and cultivation (Figure 2(b)).

\subsection{Changes in Land Cover to Other LULCs in Vikumbulu Ward}

Between 1998 and 2011, about 8\% of the forest cover was converted into bareland, settlements and cultivation, and $\sim 43 \%$ of this forest converted into 

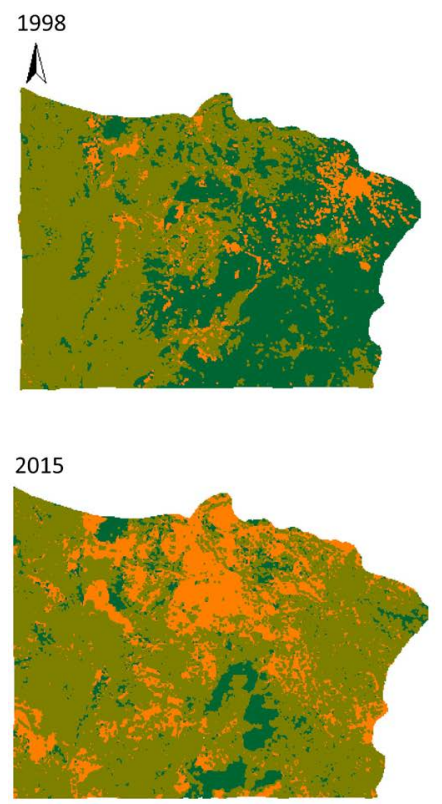

2011

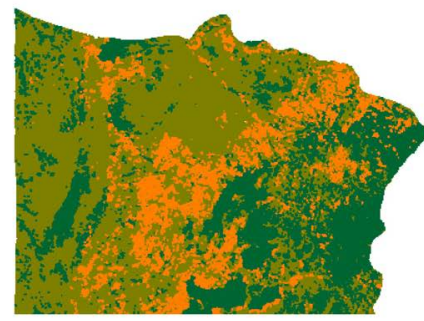

Vikumbulu 1998-2015
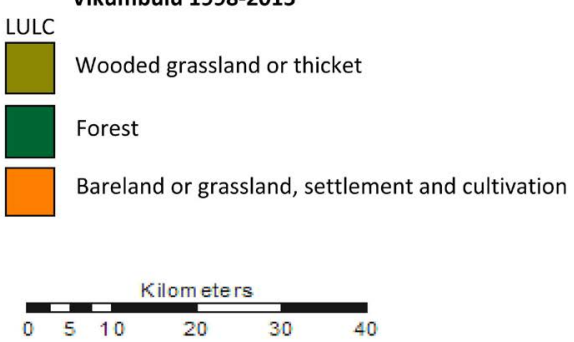

(a)

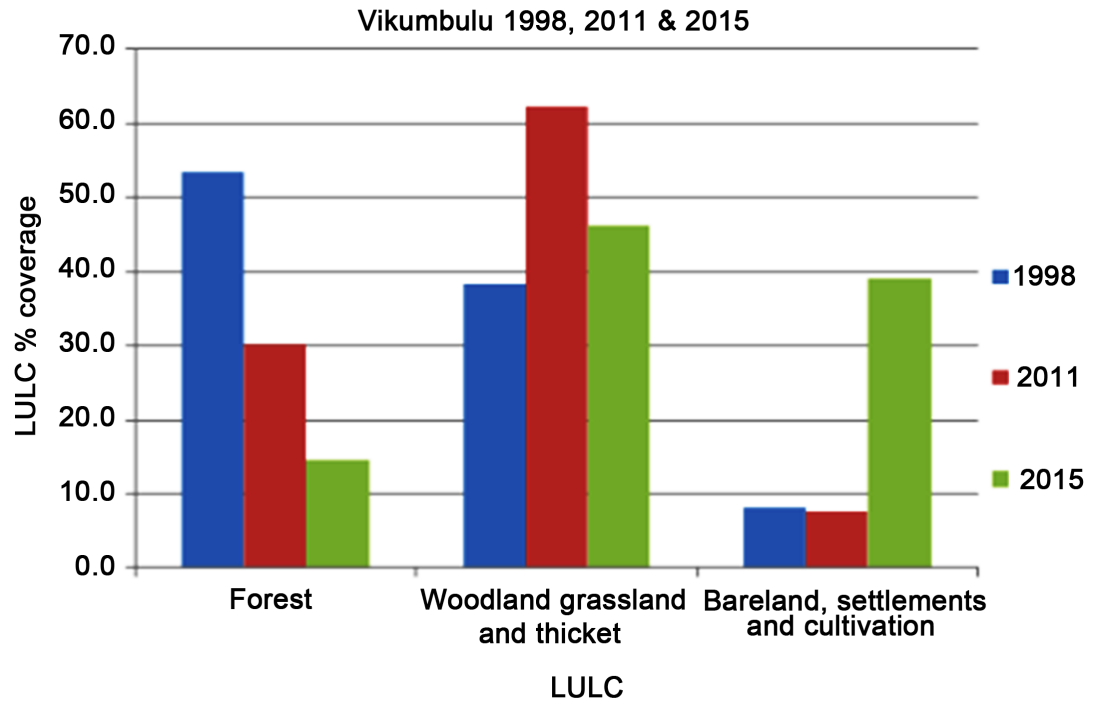

(b)

Figure 2. (a) Vikumbulu LULC classification maps showing distribution of land cover and (b) the percentage land cover of dominant vegetation classes in 1998, 2011 and 2015.

Table 3. Accuracy assessment of Vikumbulu image 2015: number of points correctly matched between classified map and ground truth (BL is "settlements/cultivation, grassland and bare ground", FC is "forest cover" and WG is "wooded grassland" and thicket).

\begin{tabular}{cccccc}
\hline LULC classes & BL & FC & WG & Grand Total (no of points) & Accuracy (\%) \\
\hline BL & 26 & & 7 & 33 & 79 \\
FC & 4 & 19 & 3 & 26 & 73 \\
WG & 24 & 1 & 65 & 90 & 72 \\
Grand Total & $\mathbf{5 4}$ & $\mathbf{2 0}$ & $\mathbf{7 5}$ & $\mathbf{1 4 9}$ & Overall 74.6 \\
\hline
\end{tabular}


wooded grassland and thicket (Figure 3(a)). Furthermore, of total 30\% of forest cover that remained in 2011(Figure 2(b)) 25\% of it was converted into bareland, settlements and cultivation while $\sim 40 \%$ of this forest cover was transformed into wooded grassland and thicket between 2011 and 2015 (Figure 3(b)). On top of that, of the remained $62 \%$ of wooded grassland and thicket in 2011 (Figure 2(b)) 44\% was transformed into bareland, settlements and cultivation between 2011 and 2015 (Figure 3 (b)).

\subsection{Percentage Changes of Forest Cover in Relation to Distance from the Road in Vikumbulu Ward}

The percentage change in forest cover from the road was $~ 65 \%-85 \%$ between 0 and $2500 \mathrm{~m}$ in Vikumbulu Ward in 1998 (Figure 4). However, the forest cover

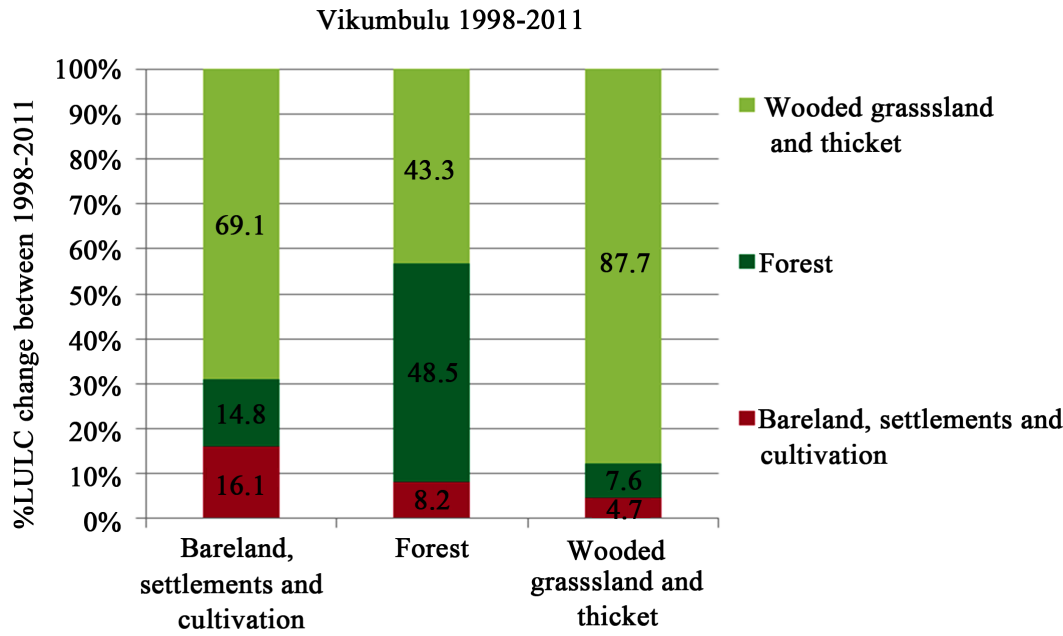

LULC 2011

(a)

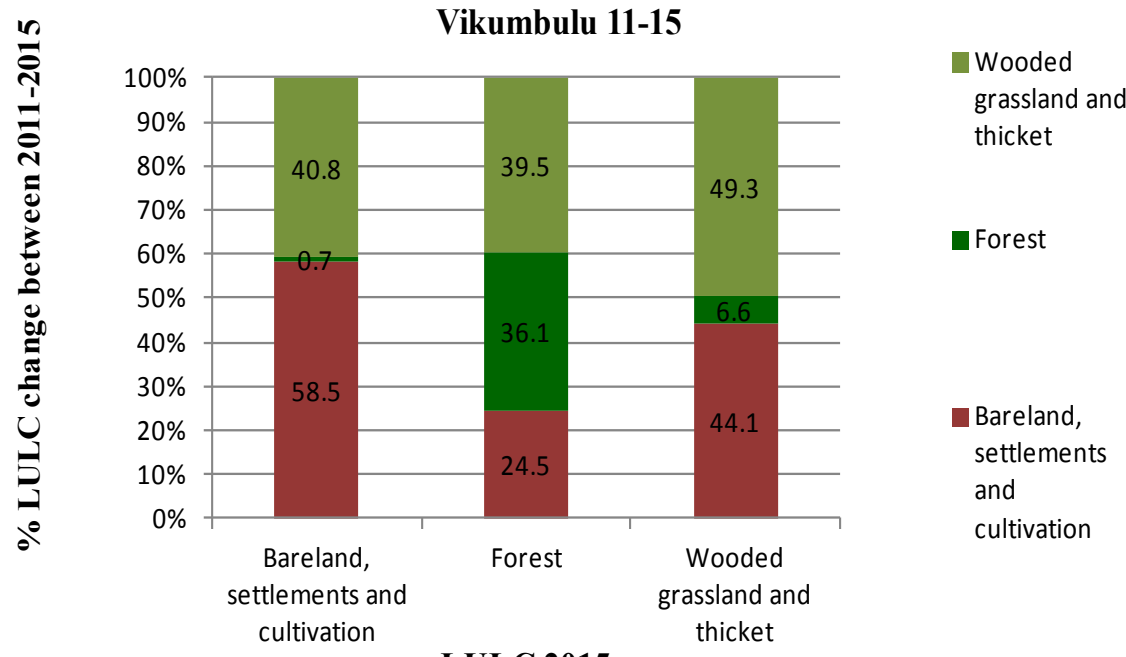

Figure 3. Percentage LULC change (a) between 1998 and 2011 and (b) between 2011 and 2015 in Vikumbulu Ward. 


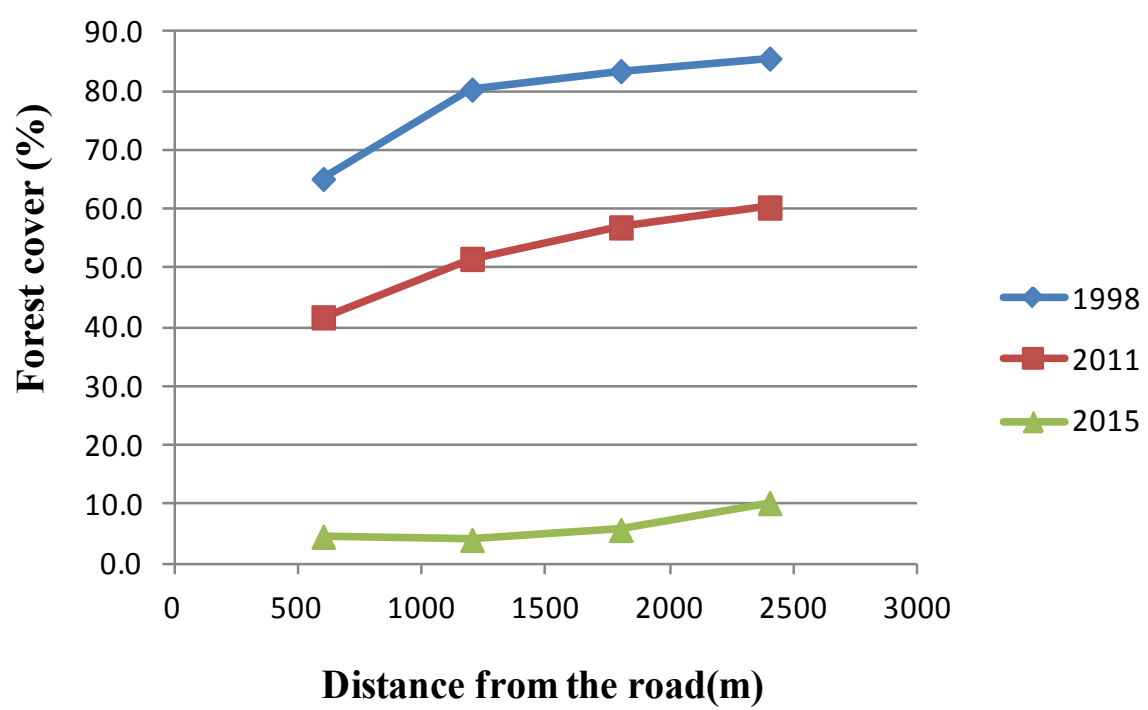

Figure 4. Percentage forests cover change with distance from the road (1998, 2011 and 2015)

declined to $\sim 40 \%-60 \%$ between the same distance of 0 and $2500 \mathrm{~m}$ by 2011 . In 2015 , there was a further decrease in forest cover to $\sim 5 \%-10 \%$, as one moves away from Vikumbulu main road.

\subsection{Trends in Demography and Cropping Activities at Vikumbulu Ward}

Human population in Vikumbulu increased from 2675 to 3257 between 1995 and 2015 while the area under crops has almost trippled by 2015 (Figure 5).

Results shows that in 1998 more than 92\% of Vikumbulu Ward was covered by forest and wooded grassland (Figure 2) while other LULC changes occupied less than $8 \%$ of the ward. By 2015 , approximately $39 \%$ of the forested area was lost suggesting increasing socio-economic activities that involves tree clearing for agriculture and charcoal burning. One of the significant, but invisible, factors contributing towards this rapid change in LULC is the energy needs of the urban centre, Dar es Salam. Villagers clears the forest to produce charcoal which is sold to people in Dar es Salam as a main source of domestic energy supply. Increasing population in the city and demand for energy exerts pressure on rural areas where people tradeoff their natural assets to obtain financial benefits for supporting livelihoods. However, there is a complete lack of planning at the local and regional scales to manage forest harvest in a sustainable manner so as to ensure continuity of income and energy supply to both rural and urban population. To achieve sustainable system of production it need an integration of socio-economic activities and natural resources management.

\section{Discussion}

Increased area of wooded grassland and thickets together with bareland, settlements and cultivation in Vikumbulu Ward, Tanzania (Figure 2) indicates 


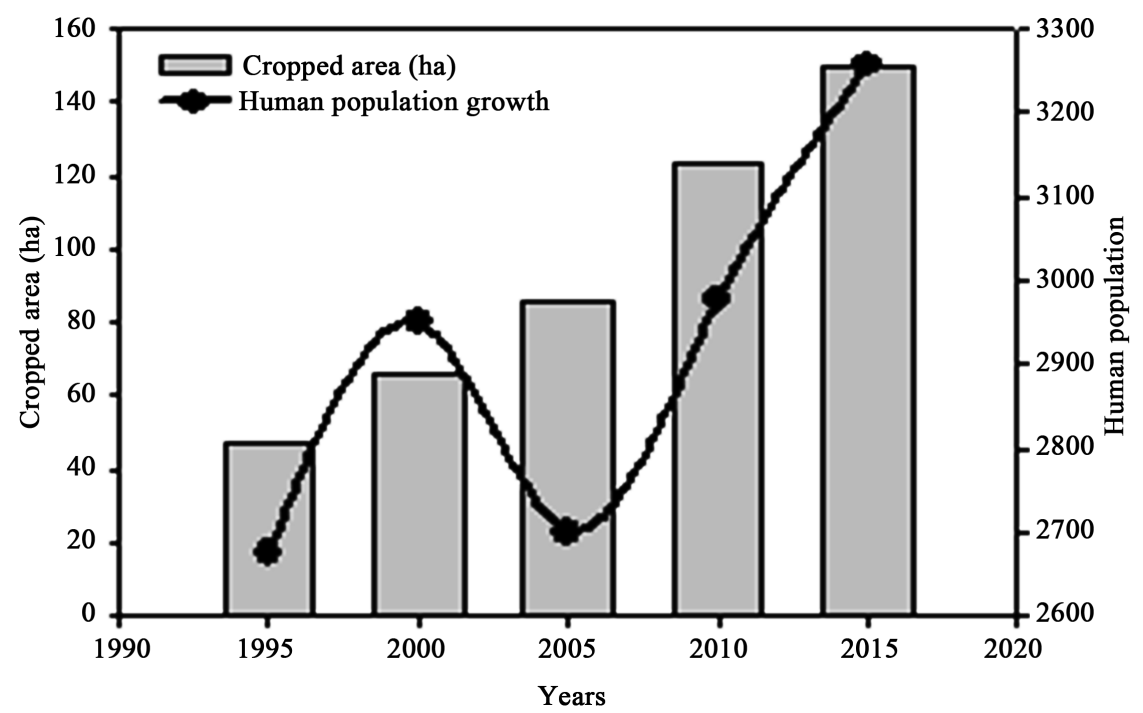

Figure 5. Population growth and area under cultivation (ha) in Vikumbulu Ward. Area under cultivation is the combination of the cassava, maizes and legumes (Source: Kisarawe District Council 2015).

deforestation around the SGR buffer zones. The LULC changes in the study ward can have serious implications for the SGR - a world's largest fauna reserve with $>350$ species of birds and reptiles.

The decrease of forest cover from 1998 (54\%) to 2015 (15\%) (Figure 2) suggests lack of government intervention in the area, thus highly risking the loss of remaining forest and woodland cover. Among the possible reasons causing such changes in the study area includes charcoal production and timber harvest, crop production. Other factors includes population growth and poverty. The first three are known to be the main sources of income for people in Kisarawe District (Mandari, 2010, Chaisamba \& Levira 2013, Makunga \& Misana, 2017). According to TNBS (2012), more than $89 \%$ of the households in Kisarawe district engage in such activities as their main source of income.

Subsistence farming is widely practiced in many rural areas rich in forestry. In most cases fertile areas which are cleared for charcoal production are used for crop production for 3 - 6 years and then left fallow for about 4 years (Luoga et al. 2000). Studies have shown this to be too short a time for tree recovery. Clearing of trees and then moving to other areas to farm, requires big areas of land, hence making subsistence farming another driver of LULC in rural communities (Luoga et al., 2000). According to Kisarawe district natural resources officer, shifting agricultural practices for maize and cassava has increased in recent years in the ward (A. Kavishe 2015, pers. comm., 13 November). This has contributed to vegetation clearing and prevents regeneration of woodland and forest. The residents in Vikumbulu ward have been selling their farms to people from Dar-es-salaam for cultivation and settlements (A Kavishe 2015, pers. comm., 13 November).

Tanzanian national and regional agriculture census of 2007/2008 (TNBS, 2012), has shown the estimated utilizable cropland nationwide to have remained 
constant at about 2 ha per household and Kisarawe household cropland cultivation to range from 0.5 ha to 1 ha per household. Therefore the total number of agricultural households in Kisarawe is estimated to be 23,356 which is $13.4 \%$ of the Pwani region in Tanzania.

The total area under cultivation by 2015 in Vikumbulu ward was 150 ha (Figure 5), which is about $0.15 \%$ of the total ward area. The population at Vikumbulu ward is estimated to be 3, 248 according to 2012 census results (TNBS, 2012). From the overall district household size of 3.8 (TNBS, 2012), the estimated number of household in Vikumbulu ward is 854 . To obtain an estimate of land under crop cultivation, the number of households can be multiplied by the district household's cropland ( $0.5 \mathrm{ha}-1 \mathrm{ha}$ ) (TNBS 2012). The estimated area under cultivation would range between 427 ha -855 ha in Vikumbulu. This is about $\sim 4 \%-9 \%$ of the total land (99,660 ha) in the ward, which is more than the current cropland from the data provided in Figure 5. Therefore the increase in agricultural area from 1995 to 2015 is very small in Vikumbulu ward when compared to the estimated area under cultivation from TNBS of 2012.

From spatial analysis (Figure 3(a)), slow transformation of forest cover and wooded grassland into bareland, settlements and cultivation between 1998 and 2011 in the Vikumbulu ward (Figure 3(a)), indicates low associated levels of natural-resource based socio-economic activites like charcoal burning and shifting cultivation at that time. However, spatial analysis (Figure 3(b)) of 2011-2015 showed an increase in bareland, settlements and cultivation with decreasing wooded grassland and forest cover in Vikumbulu ward. This means that under the given current population, the area under crop cultivation $(0.15 \%)$ is very small when compared to forest and woodland loses as shown in satellite data (Figure 2(a) \& Figure 2(b)). Thus, in this scenerio if agriculture is the driver of LULC changes, then it implies shifting cultivation will be responsible for land cover changes in Vikumbulu ward.

The changes in African ecosytems are the outcomes of land-use practices that have been caused by increasing human sprawl in rural Africa (Vanderpost, 2006), again an example of how these multiple drivers are interrelated. CHAPOSA (2002) found that charcoal demand is directly linked to urban population growth in developing countries. More than $80 \%$ of Sub-Saharan populations, with the exception of Southern Africa, depend on wood biomass as a sources of energy for cooking. It is predicted that, as the population of African urban grows, more supply of charcoal will be required to meet the growing demands (CHAPOSA, 2002). CHAPOSA (2002) found that for each $1 \%$ increases in urbanization, a $14 \%$ increase in charcoal consumption results. A study by Kalaba (2014) noted that the conversion of miombo woodedland to agriculture land is the outcome of increasing human population in miombo woodlands.

According to TNBS (2012) census, Kisarawe population was 78,290 in 1988 and 95,323 in 2002. Among them about 80,817 lived in the rural region while 14,506 lived in Kisarawe urban area in 2002. The national population census of 2012 
shows that, Kisarawe district population was at 99,635, of which 82,848 lived in rural areas and 16,787 lived in Kisarawe urban area (TNBS 2012). This large proportion of rural population in Kisarawe has implications for LULC changes and natural resources use. A Kavishe (2015, pers. comm., 13 November) said, there are increasing immigrants from Dar-es-salaam city. Increasing human population in miombo woodlands leads to shifting cultivation and increasing energy needs and hence more pressure on woodlands (Chirwa et al. $2008 \mathrm{~b}$ as cited in Kalaba 2014). Despite significant loss of forest and wooded grassland cover in Vikumbulu ward between 2011 and 2015 (Figure 1 \& Figure 2) shown by spatial data, it does not reflect its population growth. Land cover changes which are happening in the ward are not because of increasing settlements or agriculture growth due to population, but is rather the outcome of other drivers of LULC like firewood collection, logging and charcoal burning. In connection to this, Mwampamba (2007) and Hojas-Gascón et al. (2016) have found that increasing population and fuel demand in Dar-es-salaam city coupled with increasing rural poverty are factors causing resources depletion in coastal areas. Thus as a struggle to escape from poverty, population growth in Dar-es-salaam city might have indirectly influenced forest and woodland degradation in Vikumbulu ward.

Charcoal production in Tanzania is primarily conducted in state forests and public or village owned forest (Sander et al., 2013). The impacts of charcoal production is widely documented (Mwampamba, 2007). Studies suggest that in Africa almost $90 \%$ of wood removal is used for fuel (Kees \& Feldmann, 2011). In spite of agriculture being the main economic activity in rural Africa, trade in charcoal is widely practiced by rural farmers (CHAPOSA, 2002). These trends provide evidence on how charcoal business has escalated in African rural and city centres.

In Tanzania, Dar es salaam is considered to be the main consumer (about $70 \%$ ) of the charcoal produced in Tanzania, leaving areas nearby widely affected due to resources degradation (Ahrends et al., 2010). Among major reasons for growth of charcoal consumption in this city is the availability of cheap and affordable charcoal stoves in the market compared to electric and gas stoves (Luoga et al., 2000). Demand for charcoal is predicted to increase in major cities of developing countries as a result of increasing population and unaffordable sources of energy (Mwampamba, 2007).

This study shows a decrease in forest cover and an increase in wooded grassland between 1998-2011, which then followed by decreasing trend of the latter between 2011 and 2015 (Figure 1 \& Figure 2). Given small area under crop cultivation in the ward (Figure 5), this indicates that clearing for charcoal burning (Figure 6 \& Figure 7) is widespread in the ward. The estimated households charcoal consumption in Dar-es-salaam is 1000 tons of charcoal per day which is equivalent to 18,800 bags each at $53 \mathrm{~kg}$. By considering all consumers, the total charcoal consumption in Dar-es-salaam is estimated to about 24,000 bags of charcoal per day (CHAPOSA, 2002; Mwampamba, 2007). 


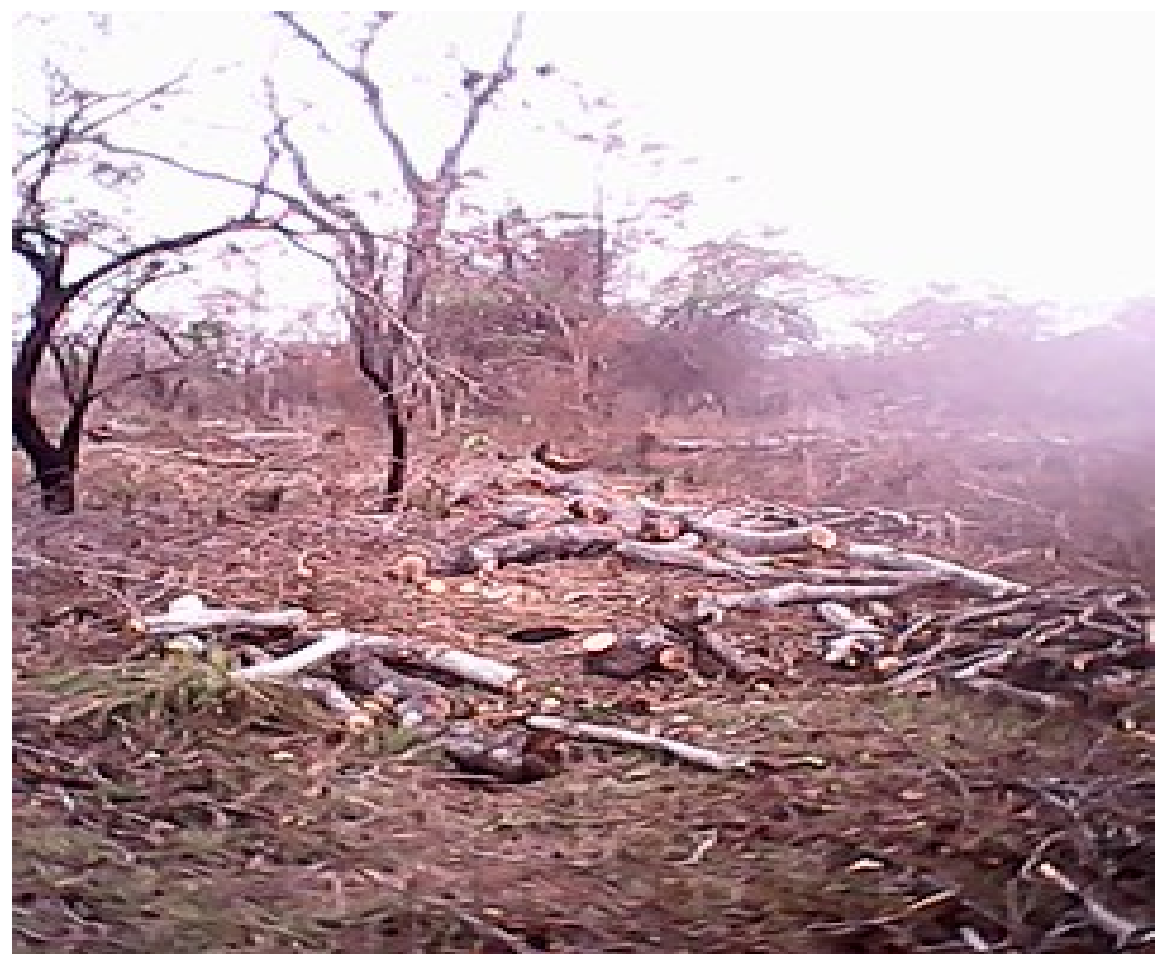

Figure 6. Woodland cleared for charcoal burning in Vikumbulu ward (Source: Nyanda 2013).

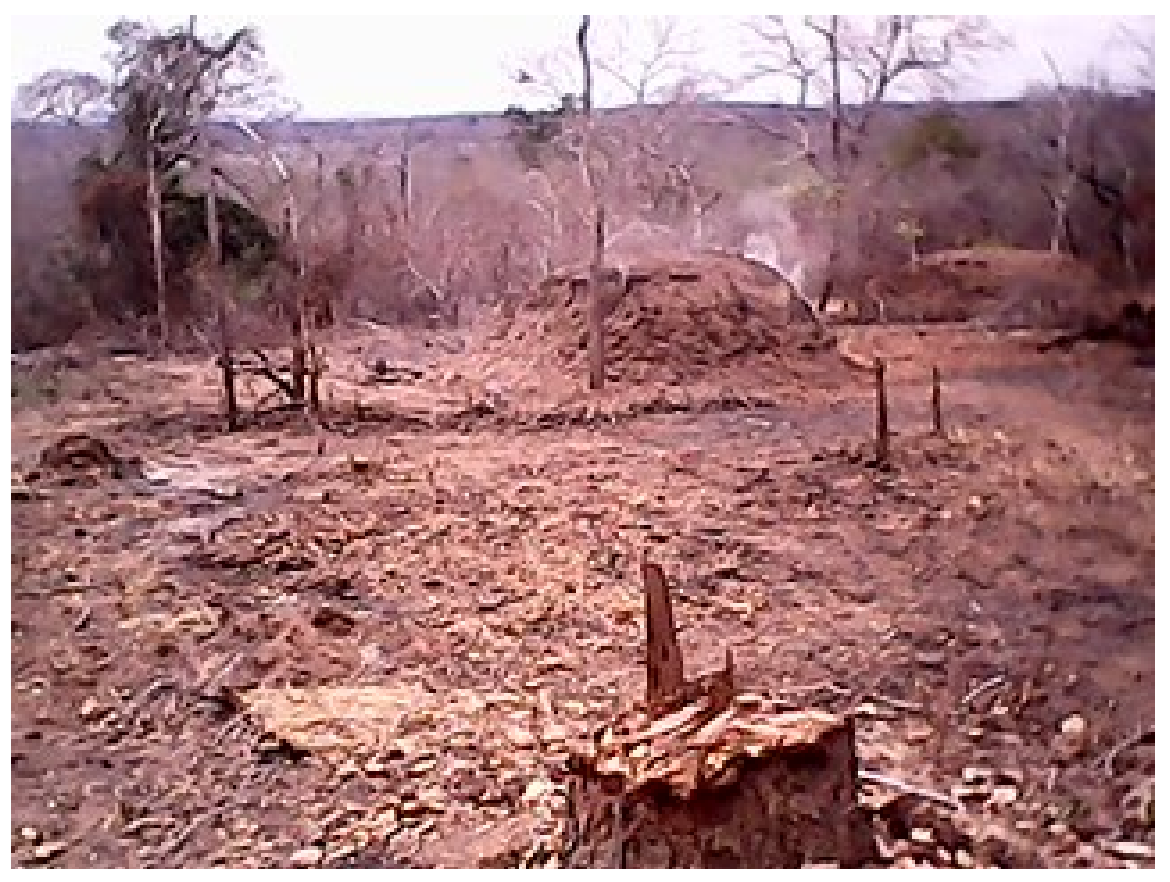

Figure 7. Charcoal burning in Vikumbulu ward (Source: Nyanda 2013).

Kavishe 2015, suggested that, the use of motorcycles has facilitated transportation and hence depletion of natural resources in the ward. It is cheap, easy and it takes only a few hours to carry a large quantity of charcoal from a charcoal kiln to the road for the wholesaler to load (A Kavishe 2015, pers. comm., 13 Novem- 
ber). Charcoal production and timber trade have been a dominant activity within Dar-es-salaam proximity (Ahrends et al., 2010). With exhaustation of biodiversity in the nearby areas, there is increased price of charcoal and timber which makes biodiversity and forest at longer distance attractive to businessmen (Ahrends et al., 2010).

Our study also testifies the same as shown in Figure 4. As one moves from 0 $\mathrm{m}$ to $2500 \mathrm{~m}$ away from the main road heading to Dar es Salaam from Vikumbulu Ward (Figure 4), there was less loss of forest cover in 1998. A rapid conversion of Vikumbulu LC between 2011 and 2015 (Figure 3) was attributed by easy access road to Dar es Salaam City. Although charcoal in Dar-es-salaam City is supplied from different nearby regions like Morogoro, Tanga, Lindi and other coastal districts, but Kisarawe District is known for charcoal exploitation by the wholesalers. This is because of short transportation distance from Vikumbulu Ward to Dar-es-Salam City, and therefore less cost.

Land cover changes, its implication on protected area buffer zones and rural livelihoods

Vegetation cover in the buffer areas, as in Vikumbulu Ward, provides important ecological habitats for wildlife animals and plant species which might not be available in the core protected area (Diego, 2001). Buffer zones also reduce encroachment in protected areas. Generally, buffer zones are critically important for conservation of highly mobile species by minimizing the edge effects and for supporting sustainable rural people's livelihoods. The impact of tree clearance for charcoal burning and timber logging will not only deplete the tree resources upon which the locals rely on, but also the future harvest of forest products (Shanley, 2002). Using different scenarios, Mwampamba (2007) predicted a complete loss of public forest cover in Tanzania by 2028. Additionally, degradation of natural resources raises the prices of firewood, an additional burden to household budgets and particularly for women and children as they have to spend more time on searching and collecting firewood (Kees \& Feldmann, 2011).

Therefore, rapid LULC changes in Vikumbulu Ward and Kisarawe rural area deplete forest resources in the buffer zone that ultimately impacts on conservation reserves, particularly the SGR, and on community livelihoods. To promote sustainable community livelihood strategies, there is a need for serious attempts from the concerned government and local agencies to collaboratively work out a plan for sustianable use of forest resources so as to meet both, the community demands as well as conservation outcomes, to help minimize resources degradation in the ward.

\section{Conclusion and Recommendation}

Analyses have shown significant land cover degradation at Vikumbulu ward bordering SGR in Kisarawe district of which, without appropriate regulations and action, the woodland and forest cover will be depleted in the future. 
There is a need to strengthen participatory community based conservation halt the ongoing land cover changes in the ward. To boost household income, establishment of village forests and wildlife management areas (WMA) should be associated with developing and promoting alternative sources of income generation to rural communities. Taking advantages of the organic and green agricultural markets in cities and tourism industry around protected area, capacity building in land use planning, intensive agriculture practices and agribusiness skills such as horticulture will increase yields per hectare and hence increase income to rural poor. Emphasis in education and training should be given to qualified rural community to create conducive environment for them to be absorbed in employment opportunities. Prioritizing rural community members to work in protected areas particularly those bordering protected areas create a sense of responsibility in taking care of forest resources and provide livelihood opportunities. Because biomass energy is the main cause of forest and woodland degradation, the government should invest in solar or gas cooker both in rural regions and urban to utilize the available sunlight and hence reduce forest use.

Without much legal restraint and public awareness, increasing LC changes will have huge implications for the SGR as well as for the future livelihood opportunities available to the local people.

\section{Acknowledgements}

We would like to acknowledge the management of Kisarawe district council for the provision of socio-economic data, and particularly Mr. Amani W. Kavishe for his support in compilation of the requested information and data about the study area.

\section{Supported}

No any fund was issued to support the study and writing of this article.

\section{References}

Ahrends, A., Burgess, N. D., Milledge, S. A. H., Bulling, M. T., Fisher, B., Smart, J. C. R., Clarke, G. P., Mhoro, B. E., \& Lewis, S. L. (2010). Predictable Waves of Sequential Forest Degradation and Biodiversity Loss Spreading in African City. Proceedings of the National Academy of Science of the United States of America, 107, 14556-14561. https://doi.org/10.1073/pnas.0914471107

Asselen, S., \& Verburg, P. H. (2013). Land Cover Change or Landuse Intensification, Simulating Land System Change with a Global Scale Land Change Model. Global Change Biology, 19, 3648-3667. https://doi.org/10.1111/gcb.12331

Bongers, F., \& Tennigkeit, T. (2010). Earthscan Forestry Library, Degraded Forests in Eastern Africa, Management and Restoration. London \& New York: Earth Scan Publishers.

Caro, T. M., Young, C. R., Cauldwell, A. E., \& Brown, D. D. E. (2009). Animal Breeding Systems and Big Game Hunting, Models and Application. Biological Conservation, 142, 909-929. https://doi.org/10.1016/j.biocon.2008.12.018 
Chaisamba, S., \& Levira, P. (2013). Analysis of the Impacts of Urban Land Use and Climate Change on Coastal Forest Ecosystem and Management. Tanzania Meteorological Agency. http://www.suanet.ac.tz/cciam

CHAPOSA (2002). Charcoal Potential in Southern Africa, Final Summary Report, Tanzania. http://coastalforests.tfcg.org/pubs/Char_Southern_Africa_CHAPOSA.pdf

Cotillon, S. (2013). Impacts of Land Cover Changes on Ecosystem Services Delivery in the Black Hills Ecoregion from 1950 to 2010. Electronic Theses and Dissertation, 1145. https://openprairie.sdstate.edu/etd/1145

Diego, M. (2001). Buffer Zones around Protected Areas: A Brief Literature Review. Electronic Green Journal, 1, No. 15. https://escholarship.org/content/qt02n4v17n/qt02n4v17n.pdf

Fisher, R. P. (2011). Tropical Forest Monitoring, Combining Satellite and Social Data, to Inform Management and Livelihood Implication, Case Studies from Indonesian West Timor. International Journal of Applied Earth Observation and Geoinformation, 16, 77-84. https://doi.org/10.1016/j.jag.2011.12.004

Foley, J. A., DeFries, R., Asner, G. P., Barford, C., Bonan, G., Carpenter, S. R., Helkowski, J. H. et al. (2005). Global Consequences of Land Use. Science, 309, 570-574.

Food and Agriculture Organization of the United Nations (2015). Global Forest Resource Assessment (GFRA) 2015 (2nd ed.). http://www.fao.org/3/a-i4793e.pdf

Goldewijk, K. K., \& Ramankutty, N. (2004). Land Cover Change over the Last Three Centuries Due to Human Activities: The Availability of New Global Data Sets. GeoJournal, 61, 335-344. https://doi.org/10.1007/s10708-004-5050-Z

Habib-Mintz, N. (2010). Biofuel Investment in Tanzania, Omissions in Implementation. Energy Policy, 38, 3985-3997. https://doi.org/10.1016/j.enpol.2010.03.023

Hansen, M. C., Potapov, P. V., Moore, R., Hancher, M., Turubanova, S., Tyukavina, A., \& Kommareddy, A. (2013). High-Resolution Global Maps of 21st-Century Forest Cover Change. Science, 342, 850-853.

Hartemink, A. E., Veldkamp, T., \& Bai, Z. (2008). Land Cover Change and Soil Fertility Decline in Tropical Region. Turkish Journal of Agriculture and Forest, 32, 195-213.

Hojas-Gascón, L., Eva, H. D., Ehrlich, D., Pesaresi, M., Achard, F., \& Garcia, J. (2016). Urbanization and Forest Degradation in East Africa-A Case Study around Dar es Salaam, Tanzania. IEEE International Geoscience and Remote Sensing Symposium (IGARSS), Beijing, 10-15 July 2016, 7293-7295.

Kalaba, F. K. (2014). A Conceptual Framework for Understanding Forest Socio-Ecological Systems. Biodiversity Conservation, 23, 3391-3403. https://doi.org/10.1007/s10531-014-0792-5

Kangalawe, R. Y. M., \& Lyimo, J. G. (2010). Population Dynamics, Rural Livelihoods and Environmental Degradation: Some Experiences from Tanzania. Environment, Development and Sustainability, 12, 985-997. https://doi.org/10.1007/s10668-010-9235-y

Kashaigili, J. J., Levira, P., Liwenga, E., \& Mdemu, M. V. (2014). Analysis of Climate Variability, Perceptions and Coping Strategies of Tanzanian Coastal Forest Dependent Communities. American Journal of Climate, 3, 212-222. https://doi.org/10.4236/ajcc.2014.32020

Kees, M., \& Feldmann, L. (2011). The Role of Donor Organisation in Promoting Energy Efficient Cook Stoves. Energy Policy, 39, 7595-7599.

https://doi.org/10.1016/j.enpol.2011.03.030 
Khorram, S., Van Der Wiele, C. F., Koch, F. H., Nelson, S. A., \& Potts, M. D. (2016). Principles of Applied Remote Sensing. Berlin: Springer. https://doi.org/10.1007/978-3-319-22560-9

Kremen, C., Niles, J. O., Dalton, M. G., Daily, G. C., Ehrlich, P. R., Fay, J. P., Grewal, D., \& Guillery, R. P. (2000). Economic Incentives for Rain Forest Conservation across Scales. Science Journals, 288, 1828-1832. https://doi.org/10.1126/science.288.5472.1828 http://www.sciencemag.org/content/288/5472/1828.full

Lambin, E. F., Geist, H. J., \& Lepers, E. (2003). Dynamics of Land-Use and Land-Cover Change in Tropical Regions. Annual Review of Environment and Resources, 28, 205-241. https://doi.org/10.1146/annurev.energy.28.050302.105459

Lambin, E. F., Turner, B. L., Geist, H. J., Agbola, S. B., Angelsen, A., Bruce, J. W., George, P. et al. (2001). The Causes of Land-Use and Land-Cover Change: Moving beyond the Myths. Global Environmental Change, 11, 261-269.

https://doi.org/10.1016/S0959-3780(01)00007-3

Long, H., Tang, G., Li, X., \& Heilig, G. K. (2007). Socio-Economic Driving Forces of Land-Use Change in Kunshan, the Yangtze River Delta Economic Area of China. Journal of Environmental management, 83, 351-364. https://doi.org/10.1016/j.jenvman.2006.04.003

Luoga, E. J., Witkowski, E. T. F., \& Balkwill, K. (2000). Economics of Charcoal Production in Miombo Woodlands of Eastern Tanzania, Some Hidden Costs Associated with Commercialization of the Resources. Ecological Economics, 35, 243-257.

https://doi.org/10.1016/S0921-8009(00)00196-8

Luoga, E. J., Witkowski, E. T. F., \& Balkwill, K. (2005). Land Cover and Use Changes in Relation to the Institutional Framework and Tenure of Land and Resources in Eastern Tanzania Miombo Woodlands. Environment, Development and Sustainability, 7, 71-93. https://doi.org/10.1007/s10668-003-4013-8

Lupala, J. M., Mdemu, M. V., \& Butungo, S. P. (2014). Effects of Peri-Urban Land Use Changes on Forest Ecosystem Services, the Case of Settlements Surrounding Pugu and Kazimzumbwi Forest Reserves in Tanzania. Journal of Geography and Geology, 6, 231-240. https://doi.org/10.5539/jgg.v6n4p231

MacKenzie, C. A., \& Hartter, J. (2013). Demand and Proximity, Drivers of Illegal Forest Resource Extraction. ORYX, 47, 288-297. https://doi.org/10.1017/S0030605312000026

Makunga, J. E., \& Misana, S. B. (2017). The Extent and Drivers of Deforestation and Forest Degradation in Masito-Ugalla Ecosystem, Kigoma Region, Tanzania. Open Journal of Forestry, 7, 285. https://doi.org/10.4236/ojf.2017.72018

Mandari, Z. (2010). Perceptions and Realities of Biofuels Investment in Rural Livelihood, the Case of Kisarawe District, Tanzania. Tema: Water and Environmental Studies Department of Thematic Studies Linköping University. http://www.diva-portal.org/smash/get/diva2:409769/fulltext01.pdf

Mdemu, M., Kashaigili, J. J., Lupala, J., Levira, P., Liwenga, E., Nduganda, A., \& Mwakapuja, F. (2010). Dynamics of Land Use and Land Cover Changes in the Pugu and Kazimzumbwi Forest Reserves. In Proceedings of the First Limate Change Impacts, Mitigation and Adaptation Programme Scientific Conference, 2012.

Meiyappan, P., \& Jain, A. K. (2012). Three Distinct Global Estimates of Historical Land-Cover Change and Land-Use Conversions for over 200 Years. Frontier of Earth Science, 6, 122-139. https://doi.org/10.1007/s11707-012-0314-2

Meiyappan, P., Roy, P. S., Sharma, Y., Ramachandran, R. M., Joshi, P. K., DeFries, R. S., \& Jain, A. K. (2017). Dynamics and Determinants of Land Change in India: Integrating Satellite Data with Village Socioeconomics. Regional Environmental Change, 17, 753-766. https://doi.org/10.1007/s10113-016-1068-2 
Millennium Ecosystem Assessment (2005). Ecosystems and Human Well-Being. Biodiversity Synthesis. Washington, DC: Island Press.

Mwampamba, T. H. (2007). Has the Woodfuel Crisis Returned? Urban Charcoal Consumption in Tanzania and Its Implications to Present and Future Forest Availability. Energy Policy, 35, 4221-4234. https://doi.org/10.1016/j.enpol.2007.02.010

National Forestry Resources Monitoring and Assessment of Tanzania (NAFORMA) (2015). Tanzania Forest Service Agency. http://www.tfs.go.tz/resources/view/naforma-report-2015

Ned, H. (2010). Remote Sensing for Ecology and Conservation, a Handbook of Techniques. Oxford: Oxford University Press.

Ramankutty, N., Evan, A. T., Monfreda, C., \& Foley, J. A. (2008). Farming the Planet: 1. Geographic Distribution of Global Agricultural Lands in the Year 2000. Global Biogeochemical Cycles, 22, GB1003. https://doi.org/10.1029/2007GB002952

Sander, K., Gros, C., \& Peter, C. (2013). Enabling Reforms, Analysing the Political Economy of the Charcoal Sector in Tanzania. Energy for Sustainable Development, 17, 116-126.

Shanley, P. (2002). Tapping the Green Market, Management and Certification of Non-Timber Forest Products. London: Earthscan.

Sunderlin, W. D., Angelsen, A., Belcher, B., Burgers, P., Nasi, R., Santoso, L., \& Wunder, S. (2005). Livelihoods, Forests and Conservation in Developing Countries: An Overview. World Development, 33, 1383-1402. https://doi.org/10.1016/j.worlddev.2004.10.004

Sunseri, T. (2005). Something Else to Burn: Forest Squatters, Conservationists, and the State in Modern Tanzania. The Journal of Modern African Studies, 43, 609-640. https://doi.org/10.1017/S0022278X05001242

Tabor, K., Burgess, N. D., Mbilinyi, B. P., Kashaigili, J. J., \& Steininger, M. K. (2010). Forest and Woodland Cover and Change in Coastal Tanzania and Kenya, 1990 to 2000. Journal of East African Natural History, 99, 19-45. https://doi.org/10.2982/028.099.0102

Tanzania National Bureau of Statistics (TNBS) (2012). http://www.citypopulation.de/php/tanzania-admin.php?adm2id=0603

Tremblay, S., \& Lowry, W. (2016). Despite Conservation Efforts, Tanzania’s Forests Still under Pressure. Mongabay Series: Global Forests. https://news.mongabay.com

Treue, T., Skeie, K., Njana, M. A., Ngowi, S. E., Isango, J. A. K., Burgess, N. D., Ngaga, Y. M., Meilby, H., Lund, J. F., Kajembe, G., Iddi, S., Blomley, T., Theilade, I., \& Chamshama, S. A. O. (2014). Does Participatory Forest Management Promote Sustainable Forest Utilisation in Tanzania? International Forestry Review, 16, 23-38. https://doi.org/10.1505/146554814811031279

Turner, B. L., Meyer, W. B., \& Skole, D. L. (1994). Global Land-Use/Land-Cover Change, towards an Integrated Study. Ambio, 23, 91-95.

Vanderpost, C. (2006). Pathways of Human Sprawl in Wilderness Buffer Zones. Population and Environment, 27, 285-306. https://doi.org/10.1007/s11111-006-0022-5 